\title{
The Battle for Professionalism in Journalism in Nigeria amidst Unethical Practices
}

\author{
Andrew Ali lbbi* \\ Mass Communication Department, Elizade University, llara-Mokin Ondo State, Nigeria
}

\begin{abstract}
Without the professional touch, the art of gathering and dissemination of news can be done by anybody. However, because of the nature of the audience who the information is meant for, it has become important that a professional should be there to put the piece of information together for public consumption, bearing in mind their diversities. The advent of the Internet has seen news evolve from the newsroom to the smartphones of almost everybody. Citizen journalism has thrown a big challenge to professional journalism today. In a country like Nigeria where politicians have turned media organizations as organs of propaganda, it is becoming difficult to distinguish a professional journalist from a praise singer. This paper intends to look at the practice of journalism from the Nigerian perspective. Such unethical practices like "brown envelope" (money given in exchange for objectivity), government and ownership influence will be the focus of this paper, citing practical examples. The paper will make use of the Utilitarian Theory of Ethics and the Social Responsibility Theory of the press.
\end{abstract}

Keywords: Brown Envelope; Professionalism; Citizen Journalism; Ownership; Utilitarianism

\section{Introduction}

Journalism in Nigeria has its roots from the days of the struggle for independence from the British colonialists. The print media played an active role in the struggle for independence in Nigeria. Nationalists like Hebert Macaulay, Nnamdi Azikiwe, Obafemi Awolowo among other set up newspapers and later on became great icons of leadership in the country, whose shoes have remained too big for the feet of modern crop of leaders in the continent to fit in. Hence, in the past, journalism in Nigeria was a profession that was credited to people of noble character. According to Adaja [1], "It is pertinent to note that Nigerian Journalism took off much earlier than the proclamation or inauguration of the Nigerian nation. Evidently, Nigerian Journalism was not guided at inception by any law or regulations." Early journalists in the country did not need to acquire journalism training to be able to write good stories. This foundation is still playing a role in defining the practice of journalism in the country, more than a century after the practice started in the country. Ownership and control play very strong roles in defining what becomes news in the country. Thus, a well written story no matter how well investigated it may be may not see the light of the day if it continuously steps on the toes of the government in power or the rich in society who constitute those that place advertisements in the newspaper or broadcast organization. Journalists are left at cross roads in the country from choosing between professionalism and survival. Amidst these confusion is the non-payment of salaries to journalists as at when due. This is despite the fact that the salaries are not even enough to take care of the basic needs of the journalists. It is common to hear the word, brown envelope (a subtle way of calling a bribe). Journalists can be spotted at the end of every media event, waiting on politicians and other rich newsmakers to give them brown envelope. In this regard, the brown envelope is seen as the motivation needed to get the story written. News makers who are in the habit of not giving brown envelopes stand the risk of being avoided like a plague by the journalists no matter how important the information they have may be. At the end of the day, the dent on the profession becomes enormous.

\section{Journalism and Ethics}

Though different scholars define who a journalist is in different ways, the 10 attributes of a journalist as given by Reuters Handbook, 2008 encompasses the meaning of who a journalist is:

- Always hold accuracy sacrosanct

- Always correct an error openly

- Always strive for balance and freedom from bias

- Always reveal a conflict of interest to a manager

- Always respect privileged information

- Always protect their sources from the authorities

- Always guard against putting their opinion in a news story

- Never fabricate or plagiarize

- Never alter a still or moving image beyond the requirements of normal image enhancement

- Never pay for a story and never accept a bribe

Journalism is a noble profession. Being the fourth estate of the realm, it gets attention from both the government of the day and the general public. Governments of countries always want to know what the journalists in the country, especially the nosy ones are up to at any point in time. Belsey et al. [2] opined that "Governments of most ideological leanings, when not actively persecuting it, have sought to censor and control it, usually with success. Owners have used it as a means of satisfying their quest for power and wealth, not to mention megalomania”. In the midst of this confusion coupled with poor pay packages in countries like Nigeria (if the salaries ever come in time)

*Corresponding author: Ali Al, Mass Communication Department, Elizade University, Ilara-Mokin Ondo State, Nigeria, E-mail: alibbie@yahoo.co.uk

Received May 30, 2016; Accepted June 15, 2016; Published June 20, 2016

Citation: Ibbi AA (2016) The Battle for Professionalism in Journalism in Nigeria amidst Unethical Practices. J Mass Communicat Journalism 6: 301. doi:10.4172/2165-7912.1000301

Copyright: (c) 2016 lbbi AA. This is an open-access article distributed under the terms of the Creative Commons Attribution License, which permits unrestricted use, distribution, and reproduction in any medium, provided the original author and source are credited. 
and other challenges that the journalists have found themselves in, unethical practices become the norm. "Yet journalism remains an honourable profession, because it has an honourable aim, the circulation of information, including news, comment and opinion. This is an honourable aim because the health of a community (especially a community that has any pretensions to democracy) depends on it" [2].

Ethics means different things to different journalists. Different moral scholars have had different versions of what they see as ethical. According to Glasser et al. [3], "Our being ethical means being accountable" the scholars emphasize ethics as a process, not merely an outcome; an argument, not merely a choice. Ethics in this tradition views disputes and disagreements as an opportunity for a public discussion open to everyone affected by what the press does; it thus expects from journalists a commitment to respond, openly and candidly, to any serious question about what they do and why they do it. Above all else, ethics understood this way depends on the competence to communicate in a way that makes clear how judgments inform choices and how principles inform judgments; it depends, therefore, on eloquence among journalists commensurate with the eloquence of their most worthy critics. Ethics is important in every profession because it serves as source of guidance against excesses by members of such professions. Irrespective of whether a journalist is reporting for a local media organization or an international one, since it is journalism is put in practice, the same ethics apply to all. According to Franklin [4] "Local and national journalism have very different jobs to do, but are the ethics of local journalists different than those who work on the nationals? Of course, the same standards are expected from both national and regional journalism". The PCC's code of practice, the National Union of Journalists' code of conduct, the BBC's producer guidelines and Ofcom's content code, all cover the ethical areas that most people believe should be considered by journalists: truth telling and accuracy, privacy, discrimination, children, vulnerable people, intrusion, corruption, damaging reputations unfairly and harassment [4]. McQuail [5] explained that: "a journalistic code of ethics refers to a set of principles of professional conduct that are adopted and controlled by journalists themselves". The scholar is of the opinion that the opinion reflects the general process of professionalism of journalism, but also the wish of the media industry to protect itself from criticism and especially from threat of external intervention and reduced autonomy. From a general point of view, the codes of ethics of one country may differ in many ways from the codes of ethics of another country as a result of differences in such things like: culture, religion, governance and other peculiar situations but Laitila [6] highlighted the following as most frequently found principles in journalistic codes: truthfulness of information, clarity of information, defence of public's rights, responsibilities in forming public opinion, standards of gathering and presenting of information and respecting the integrity of sources. Hafez [7] while reacting to the various differences with respect to the different codes of ethics of the countries of the world concluded that "there is a broad international concensus that standards of truth and objectivity should be central values of journalism." Beyond the area of news journalism, there is extensive evidence of media self-regulation in the form of voluntary codes designed mainly to protect the public from some possible harm or the industry from outside pressure [5].

\section{The Citizen vs. Professional Journalist}

Citizen journalism gained popularity with the technological success of the Internet which gave birth to the social media. According to Frankson [8] "the general notion of citizen media (and therefore the specific one of citizen journalism) can be located in a multiplicity of critiques against conventional mass media and journalism. The very idea of mass media has invited criticism by those who see the concept of 'mass' as designating a largely indistinct actual and potential audience or public for the media". The ability of the public to be involved in the packaging of news is part of the provisions of the democratic participant media theory as propounded by Denis McQuail. Part of its provision holds that the mass media have become too socially important to be left in the hands of professionals. The advent of the Internet facilitated the process of sending and receiving messages real time irrespective of distance or geographical terrain. Members of the public became empowered to manipulate what was before now the monopoly of the professional journalists. The idea of members of the public participating in journalism has received varied nomenclatures. Rosen [9] describes it thus: "When the people formerly known as the audience employ the press tools they now have in their possession to inform one another, that's citizen journalism." [10] sees the concept as: "User-generated media sites: characterized by the use of everyday citizens as reporters, usually unpaid, in the place of professional journalists. They take full advantage of interactive Web 2.0-type technologies that allow readers, reporters, and the professional staff to comment on stories, as well as to debate and discuss issues in ways that are impossible in traditional mass media." [11] called it public journalism. "Public journalism aimed to 'see people as citizens rather than as spectators, readers, viewers, listeners, or an undifferentiated mass" and to reinvigorate participatory democracy by emphasizing journalism's social responsibility". As the definitions for citizen journalism are many, so are its applications by the citizen journalists. It could be a less sophisticated device as an old fashioned still or video camera or a midget or a sophisticated smartphone with all the gadgets inbuilt to record video and audio and compose graphics. This brand of journalism has triggered revolutions in different parts of the world which resulted in change (both negative and positive). It has won the hearts of many for some of the following reasons:

\section{It gives room for freedom of speech.}

2. It allows citizens to form their own networks, thereby addressing important societal issues and calling for mass actions in situations where the need arises.

3. It allows any one to share important news irrespective of whether it is authentic or not.

4. Every citizen is his/ her own gate keeper. This has put an end to the era of editors refusing to accept some articles because of offensive content or even poorly written content.

With all these advantages above, it is obvious that too much freedom will give rise to anarchy. Matheson [12] expressed his concern on this issue thus: "A new source of concern has been opened by the rapid and widespread growth of weblog journalism (blogging) by individuals both within and also outside the walls of existing media. Singer [13] said "there is a good deal of uncertainty about the line between old and new journalistic forms". McQuail [5] put the icing on the cake by saying: "A particular problem of concern is the normative standards that can be expected from the new news blogging activity, which is not subject to accountability". In Nigeria, blogs spring up on a daily basis and most of them are involved in one form of unethical practice or the other. Of great concern is the fact that some of these bloggers and operators of social media platforms are ignorant of what constitute unethical practices with respect to crimes like plagiarism and defamation. All these social responsibility concerns point to the fact that the professional journalist is a handy man when it comes to the dissemination of credible news. 
The big question is who is a professional journalist? Literally, McQuail [5] explained that journalism refers to the product or the work of professional 'news people'. While some scholars like Kepplinger et al. [14] argue that "journalists cannot really be counted among the professional class largely on the grounds that they behave very selectively with those they have to deal with and professionals should treat everyone equally". There are obvious evidences to suggest that if a journalist acts in certain ways, members of the society will be quick to refer to the action as either unethical or unprofessional. This suggests that to avoid unethical conducts in the process of packaging and dissemination of news, a professional who will work in line with the code of ethics of journalism is the right person for the job. The international organization, Society of Professional Journalists based in Indianapolis in the United States of America believes that public enlightenment is the forerunner of justice and the foundation of democracy. Members believe that ethical journalism strives to ensure the free exchange of information that is accurate, fair and thorough. An ethical journalist acts with integrity. The Society declares these four principles as the foundation of ethical journalism and encourages their use in its practice by all people in all media: seek truth and report, minimize harm, act independently and be accountable and transparent. Professionalism in journalism becomes a necessity to act as checks and balance against the use of the media for personal vendetta and media power.

\section{Wasserman [15] defined professional journalism as follows:}

Knowing what is and isn't "news"; crafting this "news" into a "story" (a peculiarly, medium) specific, constrained format which demands not only training but lots of practice to master; and a tone of address which aims the information at the audience a particular media channel imagines itself to be speaking to/writing for. There is also a moral claim to be disinterested and dispassionate and to be working on behalf of the public, a claim known as "objectivity," which gives the operation of journalism amoral imperative that can be wielded to weed out particular types of knowledge the journalist or editor considers too high- brow, unfamiliar, arcane or partisan or even irrational/dangerous for their readers/audiences. As a result news journalists operate not simply as conduits who disseminate information but as specialists who decide what information is public- worthy and who then shape it into particular forms for dissemination. This means that journalists can police a set of boundaries around their domain and protect their autonomy as specialists in particular knowledge areas and practices.

As beautiful as this definition is, many complaints have been heard from the public with respect to unethical practices even among professional journalists. Belsey et al. [2] raised this issue, "Journalism is an honourable profession, though many of those who should care for it, often including its own professionals, have dishonoured it". In Nigeria, there are so many grey areas that need clarification when it comes to professionalism in journalism. Adaja [1] captured the confusion in this way: Practitioners are expected to be guided by a code of conduct which members are expected to comply with strictly, and to be enforced by a body acceptable to all the stakeholders. However, journalism practice in Nigeria has raised a lot of questions as to the proprietary of referring to it as a profession. The loose definition of the criteria for membership has made the profession an all-comers-affair. A closer look at journalism within Nigeria will reveal that so many factors are responsible for the challenges facing the profession. "You are just trying to make us feel good about being Journalists as though we had an important career before us. Don't you realize that all of us here are the throw-outs and outcasts from other jobs". This statement quoted by Barton [16] was an interview between the director of the
International Press Institute (IPI) in Lagos, Tom Hopkins and students of the institute during its opening ceremony. The statement points out to the fact that some people pick up a career in journalism just to make ends meet. Similarly, some pick up a career in journalism believing it will lead them to riches and when this fails to happen, frustration sets in leading to unethical practices. Having said this, it is noteworthy that the country has produced several world class journalists, including the Pulitzer award winning journalist, Dele Olojede, who was my boss at Timbuktu media in Lagos, Nigeria. The dissemination and discussion of information concerning the major problems the world and its people face is necessary to both democratic understanding and democratic action without which the problems cannot be solved. There is therefore a great opportunity for the professional journalist to contribute to the advancement of peace, prosperity and progress in a society. But can the media respond effectively? For they themselves are not free from many of the problems that contribute to the world's difficulties [2].

\section{Media Ownership and Control in Nigeria}

Belsey et al. [2] stated that "Many critics might agree with the suggestion that any man rich enough to buy a newspaper should not be allowed to own one". This statement is in line with the position of Foley [17] "ultimately it is the owners who through their wealth, determine the style of journalism we get". Harcup [17] is of the opinion that "media proprietors set the broadlines of policy for their organizations and the combination of vertical and horizontal integration (synergy) may increase pressures on journalists to cross promote other products or to keep their noses out of their company's business". According to Downie et al. [18], broadly speaking, three factors distinguish newspapers from one another: ambitions, resources and values. Ownership is probably the greatest influence on all three. Belsey et al. [2] quoted Roy Thompson as saying "I do not believe that a newspaper can be run properly unless its editorial columns are run freely and independently by a highly skilled and dedicated professional journalist. This is and will continue to be my policy". It is one thing to make this suggestion and is another thing for it to be the standard by all media owners. In Nigeria, newspapers are not published on charity nor do broadcast media operate free of charge. They are investments that must yield profit to their owners. Some of the owners set up these media organizations in the country for political reasons. It will therefore be suicidal for an editor working for a media organization belonging to a politician to publish stories that are capable of jeopardizing the political ambitions of the proprietor or his/her political party. Cases of ownership influence on journalists can be seen from the angle of stories published in the national dailies or broadcast on the electronic media. The Nation, which is owned by a member of the opposition party, is usually critical of government. The broadcast media owned by the government: The National Television Authority and the Federal Radio Corporation of Nigeria have turned to mere praise singers, painting the government in bright colours with limited paint. There cases where journalists have lost their jobs for going against the ideologies of their proprietors. There are also incidences of the government seizing a day's publication of some national dailies at the point of circulation, using armed military personnel, because of some perceived content that the government deems it offensive.

\section{Brown Envelope}

According to Nkwocha [19], Brown Envelope is "money given to reporters or editors to persuade them to write positive stories or kill a negative story..." From the perspective of Akabogu [20], Brown envelope refers to the form of gifts, drinks, food or money given in order to influence the judgment of a journalist. Whichever way one 
looks at it, Brown Envelope involves giving of money to a journalist. In other words, bribing a journalist. Though the reason for giving the money will not be stated at the point of giving, it is the amount that suggests that the giver wants something from the journalist in return. In 2014, the T.B. Joshua, the founder of the Synagogue Church for All Nations invited journalists to come and inspect the ruins of his guest house, which collapsed under mysterious circumstances leaving many people dead including non-Nigerians. After the inspection, he offered each journalist the sum of N 50,000 each. A journalist, Nicholas Ibekwe turned down the offer. The story went viral on social media. The story had it that the prophet had given each reporter the said amount to fuel their cars, after which he asked them what they were going to write with respect to the collapsed building. All the reporters who collected the money chorused that they will write whatever he wants them to write. A similar scenario had presented itself in Nigeria when in 2002, the minister of information, professor Jerry Gana was reported to have given 400 dollars each to international journalists after a press conference. According to Eke [21] those who reported the incidence were of the opinion that the minister's gesture was aimed at bribing and pacifying some foreign journalists that were in the habit of carrying uninformed and sensational stories on Nigeria. These are two out of several incidences of offering of bribes to journalists in order to influence their views on stories no matter how important such stories are. Though the name is brown envelope, such monies could be given in white envelopes and even in bank accounts of the reporters or they could translate into things like parcels of land, automobiles or even the sponsorship of a holiday to a dream country of the journalist. More worrisome and disgraceful is the manner in which some journalists go about demanding for brown envelopes after an interview with a news maker or a press conference as if it were a provision in the code of ethics of the Nigerian journalists. Brown envelope is not peculiar to Nigeria as there are reports of journalists in some African countries who have other names apart from brown envelope. Though sometimes called PR (Public Relations), to call a spade a spade, it is simply bribe. The Nigerian journalist deals on a daily basis with strong tempting reasons to encourage the practice of this unethical practice. Some of these reasons include: poor remuneration, nonpayment of salaries as at when due, pressure from friends and families through comparing the journalists with their peers in other professions with better pay packages and the economic situation of the country. Some owners of media organisations in Nigeria have been accused of referring to the identification cards given to the journalists as meal tickets. Some have been quoted as saying, "why did I give you an ID card?" whenever journalists complain of not being paid for 3, 4, 5 or 6 months or even a year or more. These incidences and others like them call for a critical examination of the brown envelope syndrome, with a view to ascertaining if it truly has a legitimate place in the practice of journalism in Nigeria and indeed, anywhere in the world. What follows, therefore, is a treatise of the brown envelope syndrome and its debilitating impact on the future of journalism in the country [21].

\section{Review Work}

\section{Utilitarianism}

This ethical theory has Jeremy Bentham and J.S. Mill as its proponents. According to Sadler [22], the theory is based on the fact that "ultimately it is the owners who through their wealth, determine the style of journalism we get what makes something good or bad, right or wrong, is that it produces the greatest amount of pleasure (or lack of pain) for the greatest number of people." Day [23] further explained that "however, all versions of utilitarianism have one thing in common: they are concerned with the consequences of an ethical judgement". In this case, the best outcome for the greatest number of people should be considered. The main points of this theory are:

1. Maximizing positive outcomes for the largest number of people, negative outcomes for lowest number of people.

2. One should chose the action which will lead to the greatest happiness (i.e., pleasure, lack of pain) overall.

3. One's own pleasure and pain only count as much as any other person's affected.

Situations that will require a journalist to use ethical judgement in making a decision about his profession arise in untidy circumstances. According to Day [23] when neither conflicting value appears to be satisfactory, we may examine third options. This option is fairness. Will collecting bribe from a newsmaker in order to write a bias story be fair on the majority of members of the society who have placed their trusts on you? Thinking along this line is the crux of the Utilitarian Theory.

\section{Social responsibility}

The idea of social responsibility in the mass media emerged as a check to the excesses of libertarianism. Day [23] said that "although this theory continues to emphasize freedom, it holds that responsibility is necessarily a partner to freedom in institutional behaviour". Hence, codes of ethics are employed by media professional bodies within different countries to serve as agents for the promotion of social responsibility. McQuail [5] gave the following as the main principles of the theory:

1. The media have obligation to society, and media ownership is a public trust

2. News media should be truthful, accurate, fair, objective and relevant

3. The media should be free but self-regulated

4. The media should follow agreed codes of ethics and professional conduct

5. Under some circumstances, government may need to intervene to safeguard the public interest

\section{Conclusion}

The debate on whether journalism is a profession or not is still going on as many scholars still believe it falls short of some requirements to place it at par with such professions as Medicine and Law. That there are codes of ethics guarding the conduct of journalists is evidence that journalism is more than just a discipline. There are so many questions yearning for answers: How many countries respect these codes of ethics? In situations where journalists are found wanting, what punitive measures are taken by the professional bodies to serve as deterrent to others? According to Adaja [1], "Nigerian Journalism today, is in deep crisis of credibility. As a result of individual, organizational, environmental and societal challenges, most of the cherished norms and values of the profession have been abused, violated and debased. A return to the traditional values of truthfulness, neutrality and impartially may return the lost glory". From pressure from owners of media organisations, politicians and wealthy members of the society to write stories in their favour to poor welfare packages, journalists in Nigeria are constantly faced with mouthwatering scenarios that always put their ethical judgements to test [24-27]. The advent of social media makes it even more challenging for the hardworking professional 
Citation: Ibbi AA (2016) The Battle for Professionalism in Journalism in Nigeria amidst Unethical Practices. J Mass Communicat Journalism 6: 301. doi:10.4172/2165-7912.1000301

Page 5 of 5

journalist who after spending so much time and resources sees his story on some blog without acknowledging him as the source of the story. In most cases, the content of the stories are distorted by the blogger to suit his/her interpretation. There is the need for the various professional bodies in Nigeria like the Nigeria Union of Journalists, The Nigerian Press Council, the Nigerian Guild of Editors to come together and fashion out ways to strengthen the values of journalism as a profession and bring back it glory.

\section{References}

1. Adaja TA (2012) Nigerian Journalism and Professionalism: Issues and Challenges. New Media and Mass Communication 5: 15-21.

2. Belsey A, Chadwick R (1992) Ethical Issues in Journalism and the Media. London: Routledge.

3. Glasser TL, Ettema JS (2008) Ethics and Eloquence in Journalism. Journalism Studies 9: 512-534.

4. Franklin B (2006) Local Journalism and Local Media: Making the Ethical News. London: Routledge.

5. McQuail D (2010) McQuail's Theory of Mass Communication. Sage Publications Ltd

6. Laitila T (1995) Journalistic Codes of Ethics in Europe. European Journal of Communication 10: 527-544.

7. Hafez K (2002) Journalism Ethics Revisited: A Comparism of Ethics Codes in Europe, North Africa, the Middle East And Muslim Asia. Political Communication 19: $225-250$

8. Frankson B (2008) Citizen Journalism and Democracy in Africa: An Exploratory Study. Highway Africa.

9. Rosen J (2008) A Most Useful Definition of Citizen Journalism.

10. Joyce M (2007) The Citizen Journalism Website Ohmy news and the 2002 South Korean Presidential Election. Berkman Centre for Internet and Society 15: 1-21.
11. Glasser TL (2000) Politics of Public Journalism. Journalism Studies 1: 683-686.

12. Matheson D (2004) Weblogs and the Epistemology of News: Some Trends in Online Journalism. New Media and Society 6: 443-468.

13. Singer JB (2005) The Political J-Blogger Normalizing a New Media form to fit Old Norms and Practices. Journalism 6: 173-198.

14. Kepplinger HM, Koecher R (1990) Professionalism in the Media World? European Journal of Communication 5: 285-311.

15. Wasserman H (2010) Tabloid Journalism in South Africa: True Story. Indiana University Press.

16. Barton F (1975) The Press of Africa: Persecution and Perseverance. The Macmillan press Ltd.

17. Foley, Harcup T (2009) Journalism Principles and Practice. Sage Publication Ltd.

18. Downie L, Kaiser RG (2003) The News about the News: American Journalism in Peril. Vintage Books Edition.

19. Nkwocha J (2004) Digital Public Relations: New Techniques in Reputation Management. Lagos: Zoom Lens Publishers.

20. Akabogu CE (2005) The Ethical Journalist and Brown Envelop Syndrome: The Way Forward. International Journal of Communication 3.

21. Eke IW (2014) Brown Envelope Syndrome and the Future of Journalism in Nigeria. International Interdisciplinary Journal of Scientific Research 1: 148-156.

22. Sadler GB (2011) Five Ethical Theories: Bare Bones for Business Educators.

23. Day LA (2006) Ethics in Media Communications: Cases and Controversies. Boston: Wadsworth.

24. Ahva L (2010) Making News with Citizens: Public Journalism and Professional Reflexivity in Finnish Newspapers. Tampere University Press.

25. Beckett C (2008) Supermedia Saving Journalism So It Can Save The World Blackwell Publishers.

26. Karlekar KD (2008) Freedom of the Press 2008: A Global Survey of Media Independence. Journalism Studies 8: 680-688.

27. Okunna CS (1995) Ethics of Mass Communication. New Generation Books. 